\title{
Understanding the Role of Traditional \& Proficiency-Based Grading Systems Upon Student Learning and College Admissions
}

\author{
Stella Erbes \\ Pepperdine University \\ McKenna Wizner \\ Pepperdine University \\ Jackie Powlis \\ Pepperdine University
}

\begin{abstract}
The purpose of this study was to determine how traditional and proficiency-based grading schemes impact student learning and college admissions. Traditional grading (e.g., $A, B, C, D, F)$ is common in secondary schools; however, proficiency-based grading (also referred to as standards-based grading, mastery learning, or competency-based education) is another system that schools have adopted to assess student learning. This mixed-method inquiry analyzed survey data from 72 college sophomores and interview data from four university admissions counselors. Data revealed that 1) students believe that traditional grading methods inadequately measure learning, yet they still prefer letter grades over the proficiency-based model, and 2) counselors evaluate a wide array of grading systems for college admission based on procedures that are not universal. Given that many post-secondary institutions have removed the standardized testing requirement of the SAT/ACT in the admissions process during the COVID-19 climate, universities must now carefully consider how to evaluate applications given the varied grading systems represented. Educational stakeholders wonder how institutions of higher education will evaluate student learning.
\end{abstract}

Keywords: assessment, grading, college admissions, higher education

\section{INTRODUCTION}

Although the traditional grading system (e.g., A, B, C, D, F) is common in secondary schools, proficiency-based grading (also referred to as standards-based grading, mastery learning, or competencybased education) is a non-traditional grading scheme that an increasing number of American schools today have also adopted to assess student learning. In the last decade, 15 state legislatures and boards of education have shifted away from traditional methods and adopted alternative measures for assessing students' learning (McKenna, 2018). Instead of assigning traditional letter grades, proficiency-based grading utilizes a series of learning standards that students are expected to fulfill. Rather than striving for an A, students aim to reach mastery in each standard. Other performance levels refer to a student's level of proficiency. Given that these varied grading schemes exist in secondary education, our research team questioned how 
students viewed the role that the traditional or proficiency-based grading systems had upon learning. Furthermore, we questioned how post-secondary institutions translated students' unique high school transcripts during the college admissions process. After considering the impact of traditional and proficiency-based grading schemes upon students' experiences and college admissions, our research team sought to answer the following questions:

a. How do college students feel about traditional and proficiency-based grading systems?

b. How do college admissions counselors consider traditional and proficiency-based grading systems when reviewing college applications?

The purpose of this study was to understand how students and university admissions counselors perceive the impact of traditional and proficiency-based grading schemes upon student learning and college admissions.

\section{PERSPECTIVES}

While traditional grading is widely recognized and utilized, proficiency-based grading has also permeated the educational system. The following section presents the research literature that investigated both grading schemes and analyzed the process (deeper learning) and the product (letter grades) that students focus upon because of these respective systems. We have also consulted literature that presents international perspectives about the college admissions process.

\section{Traditional Grading}

Traditional grading (e.g. A, B, C, D, F) has been the basis of learning for nearly all students and has been used by teachers and administrators for many years. Cox (2011) stated, "At the secondary level, report cards look pretty much as they did when the Committee of Ten convened in 1892 to consider high school reform. Letter grades (A-F) designate relative levels of student performance, and students' grade point averages (GPA) are computed on a 4-point scale" (p. 18). The majority of schools seem to favor this traditional system and are hesitant to change from what they believe to be tried and proven.

\section{Getting Answers}

Traditional grading gives students what they want: answers. In a study involving high school students, "students in 9th grade science classes believed learning to be recall of facts that the teacher's job is to simply tell students right answers, that learning is linear and straightforward, and that only 'right' answers have value" (Peters, et al., 2017, p. 21-22). Students are conditioned to narrow their focus on these "right" answers because this century-old traditional grading system places immense trust in the information that grades communicate (Marzano, 2000). However, Guskey (2001) argued that a single mark is insufficient in answering the complex questions regarding student progress. Similarly, another study involving 550 high school students indicated that students were more focused on receiving a decent grade than improving their writing when subjected to a traditional grading system (Iamarino, 2014). Product versus process is the focus of letter grades.

\section{Proficiency-Based Grading}

Proficiency grading is an up-and-coming system in secondary education with a focus on the promotion of a mastery of set skills. This grading system is based on clearly defined objectives and focused on the progress of learning, rather than just the letter grade (Nolan, 2016). According to Great Schools Partnership (2015), the goal of proficiency-based grading is to adequately equip students with the knowledge and skills that are deemed essential in school, higher education, and the workforce. Students are expected to reach proficiency in each learning standard, and if they fail to do so, they receive additional instruction, more practice time, and academic support in order to fulfill the standard. 


\section{Process vs. Product}

Rather than the end goal being the letter grade one receives, the educational focus is shifted to the process of learning and the skills acquired along the way. With proficiency-based grading, students constantly provide evidence of learning as they work toward the learning standard, and move on only once they provide adequate evidence; students have to actually learn what they are supposed to learn, and cannot simply slide by with a merely passing grade (Shea, 2017). While students tend to have more apprehension to this grading transition, research shows that teachers generally have more positive outlooks on proficiency-based grading. A study performed at 11 high-need Kentucky high schools reported that teachers who switched to proficiency-based grading believed they were "delivering better lessons because they could focus their preparation on how to teach, not what to teach" (Hochbein \& Pollio, 2015, p. 54).

\section{Terminology}

Proficiency-based grading is organized so that material is broken down into specific learning targets, or objectives, to give a more detailed explanation of students' strengths and weaknesses. The individualized approach of proficiency grading allows students to move at their own pace, with the end goal being the "mastery" of standards. The purpose of proficiency-based grading is to shift the educational mindset of students from "What did you get?" to "What did you learn?" (Pippin, 2014, p. 348). While traditional grading defines learning using quantitative methods that conclusively produce a letter grade, proficiencybased grading uses descriptive terms like approaching proficiency, meeting proficiency, or mastery of a learning standard to represent the student learning process (Scriffiny, 2008).

\section{Grades vs. Deeper Learning}

Although secondary schools are expected to assist students in developing skills that are essential for college readiness, the competitive nature of college admissions has caused student learning to focus on the product of grades rather than the process of learning. In a study involving roughly 700 students at Washington University, Verrell and McCabe (2015) revealed that only $20 \%$ of respondents indicated that they felt prepared for college. Along with this, $37 \%$ of participants reported a lack of general study skills and $34 \%$ reported that they felt that their high schools did a poor job of preparing them to study in order to deeply learn. Conley (2015) calls for a transformation of the current traditional grading system to stimulate "conceptual understanding" and "deeper learning" (p. 5). This is where proficiency-based grading could help students refocus on the process of learning. According to Sabee and Wilson (2005), most students who have met with an instructor to discuss a lower than expected grade did so with the intention of persuading the instructor to raise their grade, rather than to clarify learning goals or gaps in their understanding. The objective of mastery learning is to develop students' skills and support them in reaching a proficient level of knowledge. As students prepare for higher education, their primary focus of learning should not only be to receive the grades that will successfully admit them into college, but also to acquire the skills and knowledge that will help them succeed in college.

\section{The College Admissions Process: International Perspectives}

The research literature confirms that the process for college admission is globally inconsistent. Soares (2012) acknowledged that an old regime in which universities depend largely on grades and standardized testing to make their decisions is slowly being updated by a new regime which relies on a more holistic evaluation model. The University of Osaka in Japan is steadily making efforts to shift their admissions process to a holistic direction and is relying on organizations like the National Association for College Admission Counseling (NACAC) to foster more communication between secondary and postsecondary professionals (Rawlins \& Ishikura, 2017). Factors like grade inflation, high school quality, and the inability of grades to accurately assess student learning are among the many reasons that researchers have cited for not depending solely on students' grades to determine college admission decisions in the U.S. and Norway (Møen \& Tjelta, 2019; Goodwin, 2011; Tam \& Sukhatme, 2004). Countries like Brazil and England require standardized tests as part of the college admissions application process even though research indicates that this mechanism was not always an indicator of success in college students' achievement (Childs \& 
Stromquist, 2015; Nahai, 2013). Hiss and Franks (2015) provided evidence that an increasing trend of American colleges and universities are adopting a test-optional path to college admission and are graduating a wider range of students. Their analysis which focused on the comparison between submitters of testing, and non-submitters of testing found that non-submitters performed just as well in college as submitters.

Sternberg's "theory of successful intelligence, or WICS, which stands for wisdom, intelligence, creativity, synthesized" (Sternberg, et al., 2012, p. 31) has also provided the framework for tests of more creative and practical skills using multiple-choice, open-ended measures and situational judgment questions. From the literature reviewed for this study, it is clear that institutions of higher education have not adopted a uniform method of processing applications. The role that varied grading systems play in the college admissions is unclear. Soares (2012) questioned, "Are we striving to select and to educate creative, cultural omnivores, active citizens, and ethical contributors to our world? Or are we looking for and rewarding the consummate multiple-choice test taker? Do we want youths who excel at "gaming" the system, or are we after those who are really open to learning and growth?" (p. 66). These are questions that still remain unanswered.

\section{METHODOLOGY}

This is a mixed-method study that analyzed how college students and university counselors perceive how traditional and proficiency-based grading schemes affect student learning and the college admissions process. Surveys from 72 college sophomores provided both numerical and descriptive data. The survey asked for specific information about the student's high school grading system and the impact of classroom assessment upon learning in high school and college. Additionally, a group interview with four university admissions counselors was audio recorded and roughly transcribed. Researchers followed an interview guide to inquire about the role of grades in the college application process. All data were collected between August 2018 and July 2019.

\section{Participants: Survey Respondents}

For this study, 75 second-year college students completed a 15-question Google Forms survey. The participant pool consisted of 56 females and 19 males, which is reflective of the 3:1 gender ratio at the college that the majority of the respondents attended. Participants were randomly selected from three universities in southern California based on ease of accessibility (i.e., peer relationships, residence halls, mutual classes, dining hall); our research team had personal connections at these four-year institutions. All of the students attended public or private high schools, and reported GPAs ranging from 3.0 to 4.85, with a 4.0 GPA being the mean. From this participant pool, two respondents (one female and one male) graduated from high schools that had adopted a proficiency-based grading system, and one student was homeschooled. For the purpose of this study, we ultimately focused on analyzing data collected from the 72 respondents (54 females and 18 males) who graduated from high schools that had employed traditional grading systems. Thus, criteria for student participation in this study included:

1. Graduated from a public or private high school that adopted a traditional grading system

2. Enrolled in a four-year university

3. Completed one full year of coursework at a four-year institution

\section{Survey: Introduction}

Prior to completing the survey, students were provided with a digital consent form and a brief written explanation about the format of both grading systems (see Appendix). The introduction to the survey explained, "Traditional grading assesses students through tests, quizzes, and homework. This system utilizes letter grades of A, B, C, D, F," and "Proficiency grading is focused on the progress of learning, rather than just the letter grade. Students have the ability to retake summative assessments in order to prove their proficiency. This system utilizes grades of mastery (MAS), advanced (ADV), meets (MTS), approaching (APP), and beginning (BEG)." Obtaining the participants' consent and defining the terms for traditional and proficiency-based grading served as the introduction to the survey. 


\section{The Survey Instrument}

The 15-question survey consisted of three main sections:

1. Demographics: Five multiple-choice and short-answer questions

2. Role of Grades College Preparation and Learning: Four Likert-scale questions

3. Grading Systems: Six open-ended questions

The demographic questions provided background information for each respondent, which helped determine the characteristics of the participant pool as a whole using gender, high school GPA, high school and college attended, and high school grading system. Next, four Likert-scale questions asked participants to describe how strongly they agreed with statements that related to the role of grades in college preparation and learning. One question posed, "In high school, I was generally more concerned about my grades than learning the content in my classes," and asked students to respond on a scale of 1-5 (1 being strongly disagree, and 5 being strongly agree). Finally, six open-ended questions that allowed students to describe their feelings toward grading systems and classroom learning in their own words. One question that revealed noteworthy findings asked, "How did your high school's grading system affect your view towards learning and education in general?" (see Appendix). The survey collected quantitative and qualitative data that provided insightful empirical evidence about students' perceptions of grading systems and learning.

\section{Survey Analysis}

Google Forms automatically summarized the numerical data from the survey into graphs. Open-ended responses were captured in a spreadsheet and then coded. By applying a grounded theory approach, our research team looked for "small chunks of material that might be put into categories, which can be provisionally labeled or named, and for wider themes and patterns which help organize the categories" (Robson, 2007, p. 131). For example, after reading the answers to question \#13 (How specifically did your high school's grading system fail or help you for your college academic experience?), each cell on our spreadsheet which represented a response was color coded to fit one of the following labels: $1=$ same as college, $2=$ focused too much on grades, $3=$ both $1 \& 2$, and $4=$ depends on the teacher, $0=$ no comment . Then, each code was counted to summarize the numbers of the various responses which were received. This coding method helped us to organize and analyze the survey data.

\section{Participants: College Admissions Counselors}

Our research team conducted a group interview with four admissions counselors on August 29, 2018. The participants were two male and two female counselors who together combined for 13 years of experience in college admissions. Given that the faculty mentor for this study knew the Associate Director of Admissions personally, ease of accessibility facilitated the selection of informants. After explaining the purpose of our study to the Associate Director, she expressed interest in participating in the project and helped recruit other counselors. She also suggested a group interview format so that the setting could support an environment in which the participants would be more forthcoming as they built upon each other's responses. The hour-long interview took place in the Associate Director's university office. All informants consented to allowing the data to be audio recorded and roughly transcribed for analysis. Using an interview guide, researchers inquired about how counselors consider varied grading systems in the admissions process and how they view the role of traditional and proficiency-based grading systems in college applications and in student learning.

\section{Interview Guide for College Admissions Counselors}

Researchers followed an interview guide which helped gather data about how college counselors translate traditional and proficiency-based grading schemes in the admissions process and how they view the roles of these unique grading systems in measuring student learning. The interview guide covered three main sections:

1) Grades: Admissions \& College Preparedness

2) Learning: Traditional vs. Proficiency-Based Grading

3) Learning: Grading Systems in College. 
These large topics served as the umbrellas under which we designated our main questions, which then led to further probing. For example, in the first section addressing the role of grades in the admissions process, one question that yielded a robust discussion was: What types of grading systems do you see when reviewing students' applications? Subsequent questions that explored this topic deeper included:

a. What is the most common form of grading found in applications?

b. What percentage of applicants come from traditional grading? Proficiency-based? Other?

c. How do you see families manipulating grading systems for college applications?

Admissions counselors also thoughtfully responded to the question: How are grades considered when reviewing college applications? Their responses demystified the college admissions process and interestingly revealed that there is no standard process that all universities follow. After probing further, informants expanded answers to: How heavily are grades weighted in the admissions process? This led to further questions about how to equalize the admissions process given the diverse grading systems represented in applications.

During our interview, respondents naturally shared their views on traditional grading which was defined as using letter grades (A, B, C, D, F) vs. proficiency-based grades which were systems that did not use letter grades. Before arriving at the final section of our interview guide, which covered the counselors' views on grading systems in college, the respondents shared that they had little to no connection to students' grades after the admissions process was completed. At the end of the interview, the counselors shared their general perceptions and some suggestions for traditional and proficiency-based grading systems in post-secondary institutions, but the majority of our interview was dedicated to the first two sections of the interview guide (see Appendix).

\section{Interview Analysis}

The interview was audio recorded and roughly transcribed. Responses from each counselor were formatted in a table so that comparisons could be easily made using a manageable format. Significant quotes were extracted from the transcripts and included in the tables for reference.

\section{RESULTS}

Data revealed that 1) students believe that traditional grading methods inadequately measure learning, yet they still prefer letter grades over the proficiency-based model, and 2) counselors evaluate a wide array of grading systems for college admission based on procedures that are not universal. Results from our study prompt educational stakeholders to question if grades accurately represent student learning and ask college counselors to reveal how grades are translated in the admissions process.

\section{Likert-Scale Survey Responses: Students' Perceptions of Traditional Grading}

In response to our survey, $97 \%$ of the students agreed that they were more concerned with their letter grades in high school than with their learning (Figure 1). Students' open-ended responses supported the sentiment that students viewed the traditional grading system in high school as a "game" to achieve the highest grade point average. 
FIGURE 1

TRADITIONAL GRADING: FOCUS ON GRADES MORE THAN LEARNING

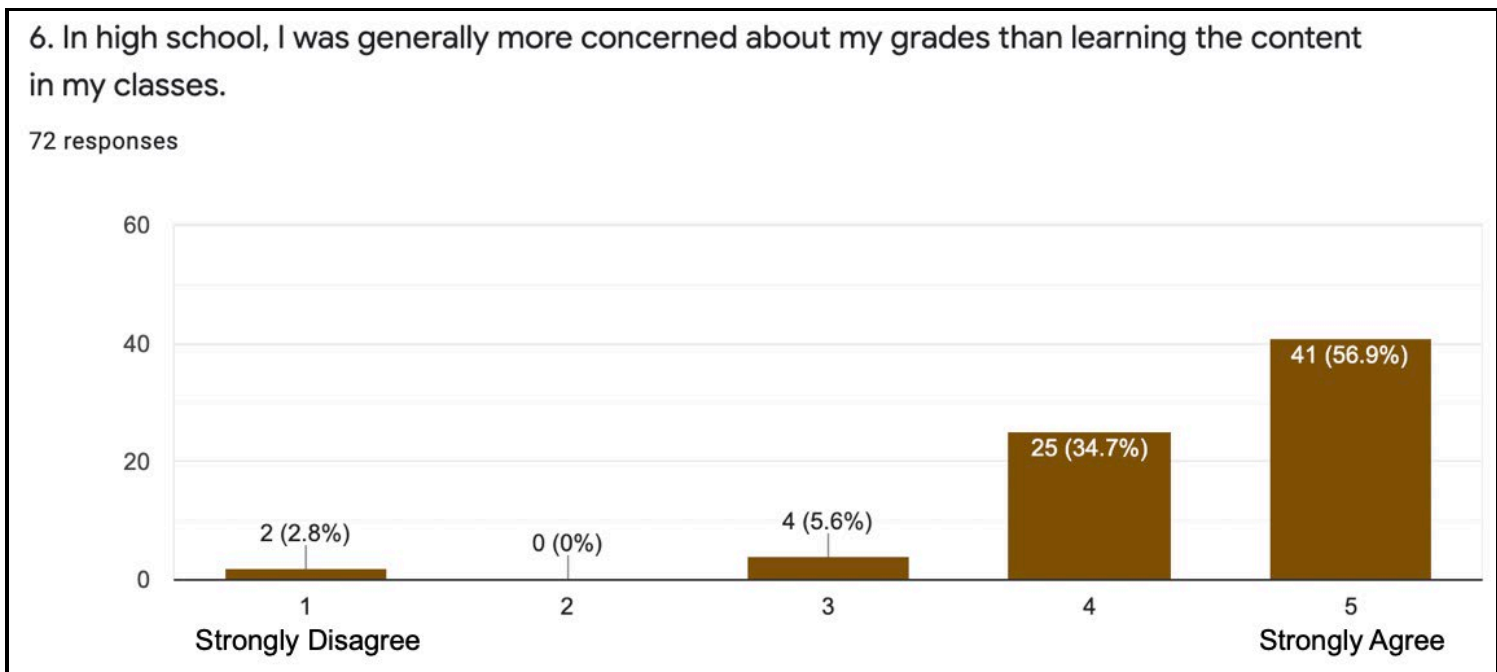

Interestingly, $88 \%$ of the students agreed that the traditional grading system prepared them well for college given that their institutions of higher education adopted traditional grading systems as well (Figure 2).

FIGURE 2

\section{STUDENTS' PERCEPTIONS: TRADITIONAL GRADING PREPARED THEM FOR COLLEGE}

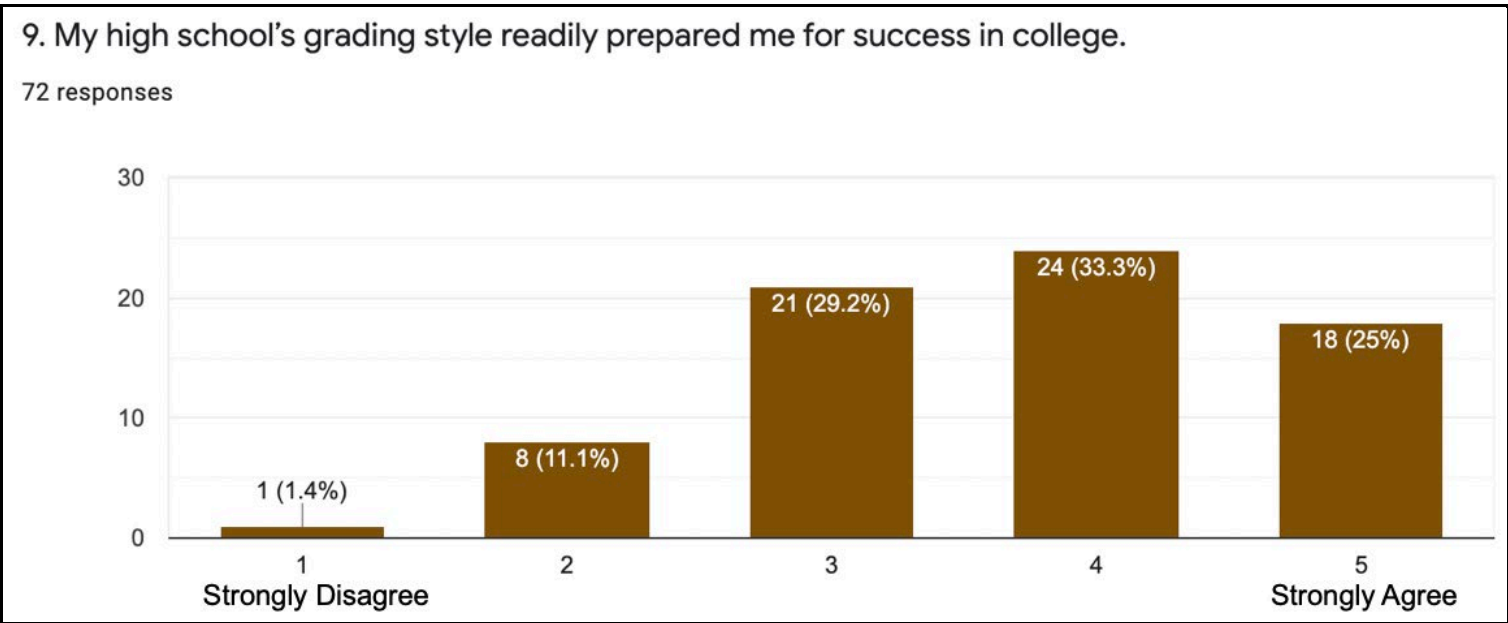

When asked about the difficulty level of their courses, $81 \%$ of the students agreed that their college courses had been significantly more difficult than their high school counterparts because universities expected deeper learning and not just memorization of facts (Figure 3). 


\section{FIGURE 3 \\ STUDENTS' PERCEPTIONS: \\ COLLEGE COURSES MORE DIFFICULT THAN HIGH SCHOOL}

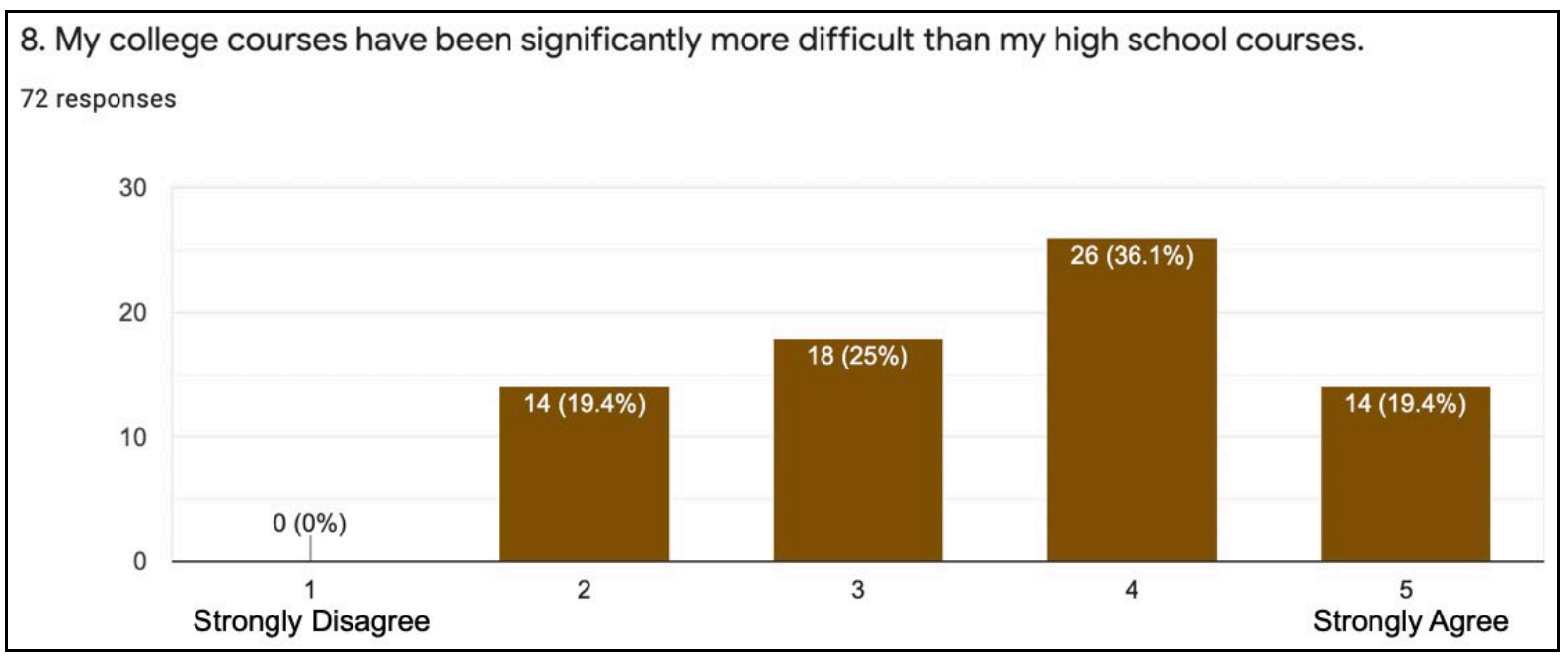

\section{Open-Ended Survey Responses: The Impact of Grades on College and Learning}

After reviewing the qualitative data, we found that $72 \%$ of the students felt that the traditional grading system supported viewing learning like a game. In other words, students prioritized "letters and GPA points rather than actually retaining information." After reflecting on the impact their relationship with grades in high school had upon their college experiences, one student wrote, "I focused more on getting grades than I did on learning material I needed for college." Similarly, another student commented, "I never learned how to study." Our results confirmed the findings revealed in the research literature which concluded that young college students expressed that college exams require more reading and synthesis of deeper learning, rather than just memorizing facts, a method they may have been able to rely on in high school (Conley, 2015; Verrell \& McCabe, 2015). Finally, 60\% of students reported that they would choose traditional grading if they were an administrator. Students accepted traditional letter grades as a standardized assessment method for education. "It's what kids know," and "It's how colleges grade," students commented. Coincidentally, $60 \%$ of students also reported that traditional grading helped their learning in some way in high school and prepared them for college.

\section{Interview Results: Grading Systems and College Admissions}

The four admissions counselors interviewed for this study confirmed that college applications contain not only different types of grading systems, but also transcripts representing a wide array of classes from various types of institutions (e.g., homeschooling, public and private schools, and community colleges). Trying to understand students' academic performance given these variables is challenging. As a result, counselors have had to engage in rigorous training and rely on norming instruments like standardized tests to assist them in evaluating students' learning potential. 
TABLE 1

\section{SURVEY DATA FROM COLLEGE STUDENTS}

\begin{tabular}{|c|c|c|c|c|}
\hline 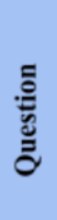 & $\begin{array}{l}\text { 11. How did you feel } \\
\text { about the grading system } \\
\text { your high school used? } \\
\text { How did it help or hinder } \\
\text { learning while in high } \\
\text { school? }\end{array}$ & $\begin{array}{c}\text { 12. If you were a high school } \\
\text { administrator, which } \\
\text { grading system (traditional } \\
\text { or proficiency) would you } \\
\text { be more inclined to adopt } \\
\text { and why? }\end{array}$ & $\begin{array}{l}\text { 13. How specifically did your } \\
\text { high school's grading system } \\
\text { fail or help to prepare you for } \\
\text { in your college academic } \\
\text { experience? }\end{array}$ & $\begin{array}{l}\text { 14. How did your high } \\
\text { school's grading system } \\
\text { affect your view towards } \\
\text { learning and education in } \\
\text { general? }\end{array}$ \\
\hline 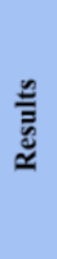 & $\begin{array}{c}\text { Helped }=23 \\
\text { Good } / \mathrm{Bad}=20 \\
\mathrm{Bad}=29\end{array}$ & $\begin{aligned} \text { Traditional } & =\mathbf{4 3} \\
\text { Proficiency } & =27 \\
\text { Uncertain } & =2\end{aligned}$ & $\begin{array}{c}\text { Same system as college }=\mathbf{3 0} \\
\text { Focused on grades/short-term } \\
\text { memory }=15 \\
\text { Same system as college }+ \text { focused } \\
\text { on grades }=10 \\
\text { Depended on the teacher }=4 \\
\text { No real explanation }=13\end{array}$ & $\begin{array}{c}\text { Helpful }=9 \\
\text { Focused on grades/game }=\mathbf{5 2} \\
\text { Helpful }+ \text { focused on } \\
\text { grades } / \text { game }=5 \\
\text { No real explanation }=6\end{array}$ \\
\hline$\stackrel{\mathscr{E}}{0}$ & $\begin{array}{l}\text { "Helped. Same as my } \\
\text { current university." } \\
\text { "I thought it was } \\
\text { challenging but it prepared } \\
\text { me for college." } \\
\text { "I was more concerned with } \\
\text { my grades than the } \\
\text { knowledge I was taking in." }\end{array}$ & $\begin{array}{l}\text { "Traditional because it's the } \\
\text { most common form of } \\
\text { grading and the easiest to } \\
\text { understand." }\end{array}$ & $\begin{array}{l}\text { "I don't know how to study and } \\
\text { college requires you to } \\
\text { understand content and not just } \\
\text { memorize." } \\
\text { "I focused more on getting } \\
\text { grades than I did on learning the } \\
\text { material for college." }\end{array}$ & $\begin{array}{l}\text { "I was more focused on } \\
\text { getting good grades for the } \\
\text { college process, as opposed to } \\
\text { just doing my best to learn." } \\
\text { "It is about numbers." }\end{array}$ \\
\hline 兽 & $\begin{array}{c}\text { Equal distribution. } \\
\text { Students found benefits and } \\
\text { detriments to the traditional } \\
\text { grading system. }\end{array}$ & $\begin{array}{l}\text { Students were most familiar } \\
\text { with traditional grading. } \\
\text { Confirms research literature } \\
\text { that states that the traditional } \\
\text { system offers a universal } \\
\text { common understanding. }\end{array}$ & $\begin{array}{l}\text { Students appreciated how } \\
\text { traditional grading helped prepare } \\
\text { them for college but also } \\
\text { acknowledged its limitations (no } \\
\text { deeper learning) }\end{array}$ & $\begin{array}{l}\text { Traditional grading system } \\
\text { caused students to focus on } \\
\text { product vs. process. }\end{array}$ \\
\hline
\end{tabular}

\section{Non-Standardized Training Among Universities}

Although college counselors view a variety of grading systems when reading applications, a standardized method to process applications does not exist among all post-secondary institutions. For example, Counselor B described a unique college application as one that displayed traditional grades from a public high school, along with dual enrollment at a community college and IB/AP credits. Additionally, Counselor $\mathrm{C}$ shared that homeschooling candidates commonly possess grade point averages that are 4.0 or higher, and their parents often submit non-traditional transcripts using stickers or anecdotal and qualitative notes. Therefore, Counselor D explained that the admissions counselors at her institution undergo "an extensive reader training" to calibrate their decision process, and confirmed that this training is not standardized across all institutions of higher education (Sorey and Duggan 2008). As a result, the role of grades in the college admission process across post-secondary institutions remains arbitrary and vague.

\section{Leveling Grading Systems}

Counselor A explained that efforts are made in the initial steps of the application process to norm the grading data by having the records team recalculate and unweight the grade point averages so that applications can be compared using a standard 4.0 system. "If there is a different grading scale...or if there are instances where no one can provide the equivalency, then we have to try to understand what kind of academic context the student is coming out of and what kind of resources they have available to us (high school profile) which can help understand how the student performed." However, simply converting grade point averages to the same 4.0 scale does not account for the abundant variables that are present across students' academic experiences (i.e., grading system, rigor of classes, AP/IB courses, high school quality). 


\section{The Role of Standardized Testing}

Translating traditional and proficiency-based grading systems represented in college applications remains challenging. Counselor $\mathrm{C}$ commented, "Sometimes it's difficult to understand just how rigorous those [community college] courses were and how they would compare to the much more standardized AP/IB courses." This counselor's response expressed support for standardized testing like Advanced Placement (AP) or International Baccalaureate (IB) to level out the ambiguous nature of grades represented when using both traditional and proficiency-based grading systems in the different contexts for learning. Counselor D affirmed the need for standardized testing to play a role in the college admissions process because the competition for college entrance is intense, and leveraging different grading systems to gain an edge over others is a strategy that both students and families have employed. Relying on scores from standardized tests like the SAT and ACT to better understand students' academic performance abilities has been one way to contextualize the increasing numbers of homeschooled students with grade point averages over 4.0.

TABLE 2A

\section{INTERVIEW DATA FROM COLLEGE ADMISSIONS COUNSELORS}

\begin{tabular}{|c|c|c|c|c|}
\hline & Counselor A & Counselor B & Counselor C & Counselor D \\
\hline Gender & Female & Male & Male & Female \\
\hline Experience & 2.5 years & 1 year & 3.5 years & 6 years \\
\hline $\begin{array}{c}\text { Challenges in } \\
\text { Reviewing Grades for } \\
\text { College Admissions }\end{array}$ & $\begin{array}{l}\text { Non-standardised grades: } \\
\text { - Weighted grades } \\
(4.0+\text { GPA }) \\
\text { Translating } \\
\text { non-traditional } \\
\text { grades }\end{array}$ & $\begin{array}{l}\text { Understanding unique } \\
\text { profiles: } \\
\text { - Dual enrollment at a } \\
\text { community college } \\
\text { - IB/AP } \\
\text { - Different forms of } \\
\text { curriculum }\end{array}$ & $\begin{array}{l}\text { Understanding the rigor of } \\
\text { different systems: } \\
\text { - Dual enrollment at } \\
\text { community college } \\
\text { - IB/AP courses } \\
\text { - online courses } \\
\text { - homeschool }\end{array}$ & $\begin{array}{l}\text { More homeschooled } \\
\text { students with 4.0+ GPAs }\end{array}$ \\
\hline $\begin{array}{l}\text { Solution to Challenge of } \\
\text { Diverse Grading Systems }\end{array}$ & $\begin{array}{l}\text { If there is no equivalency to } \\
\text { standard grade, then } \\
\text { counselors look at overall } \\
\text { high school student profile. }\end{array}$ & $\begin{array}{l}\text { "Doing your best to } \\
\text { compare and contrast" }\end{array}$ & $\begin{array}{l}\text { Look at extracurricular } \\
\text { activities } \\
\text { See if students challenge } \\
\text { themselves with their } \\
\text { commitments }\end{array}$ & $\begin{array}{l}\text { Compare student to national } \\
\text { average on standardiSed } \\
\text { tests } \\
\text { Extensive reader training }\end{array}$ \\
\hline $\begin{array}{c}\text { How They Learn of } \\
\text { University Students' Profiles }\end{array}$ & $\begin{array}{l}\text { Study the student body; } \\
\text { academically inclined, } \\
\text { spiritual, involved in campus } \\
\text { life }\end{array}$ & $\begin{array}{l}\text { Meet with Divisional Deans } \\
\text { annually } \\
\text { Learn from student workers }\end{array}$ & $\begin{array}{l}\text { Learn from student body or } \\
\text { student workers }\end{array}$ & Rely on alumni \\
\hline $\begin{array}{c}\text { Perceptions of } \\
\text { Traditional vs. Proficiency } \\
\text { Grading }\end{array}$ & $\begin{array}{l}\text { "I feel like a lot of our } \\
\text { problems with traditional is } \\
\text { that the students are } \\
\text { ascribing the letter grade to } \\
\text { their worth and I feel like } \\
\text { we are trying to get away } \\
\text { from that, but if we } \\
\text { completely switch to } \\
\text { proficiency, won't we see the } \\
\text { same thing?" }\end{array}$ & $\begin{array}{l}\text { "I think traditional grades } \\
\text { are extremely helpful. There } \\
\text { has to be some type of } \\
\text { quantitative way to } \\
\text { distinguish students when } \\
\text { viewing them for undergrad } \\
\text { or grad schools; this helps } \\
\text { give more info about the } \\
\text { student." }\end{array}$ & $\begin{array}{l}\text { "Proficiency grading seems } \\
\text { a little more labor intensive } \\
\text { for the professor and requires } \\
\text { a student who actually wants } \\
\text { to absorb the knowledge } \\
\text { which are two rare } \\
\text { components...but overall } \\
\text { seems better for the student } \\
\text { and I like the philosophy } \\
\text { behind it." }\end{array}$ & $\begin{array}{l}\text { "I would prefer the move } \\
\text { toward proficiency grading } \\
\text { systems, but it would be hard } \\
\text { to determine the scale of it } \\
\text { and communicate it to } \\
\text { students and then to graduate } \\
\text { schools." }\end{array}$ \\
\hline $\begin{array}{l}\text { Future of Classroom } \\
\text { Assessment in College }\end{array}$ & \multicolumn{4}{|c|}{$\begin{array}{l}\text { Proficiency grading could be inserted for general education classes like public speaking or first-year seminar and traditional } \\
\text { grading could be applied in major classes. }\end{array}$} \\
\hline
\end{tabular}


TABLE 2B

INTERVIEW DATA FROM COLLEGE ADMISSIONS COUNSELORS

\begin{tabular}{|c|c|c|c|c|}
\hline & Counselor A & Counselor B & Counselor C & Counselor D \\
\hline Gender & Female & Male & Male & Female \\
\hline Experience & 2.5 years & 1 year & 3.5 years & 6 years \\
\hline $\begin{array}{l}\text { Description of Ideal Student } \\
\text { Applicant Profile }\end{array}$ & $\begin{array}{l}\text { Student has a desire to } \\
\text { succeed academically even } \\
\text { if maybe they haven't done } \\
\text { as well in high school or on } \\
\text { standardised tests } \\
\text { Student exhibits the desire to } \\
\text { pursue education } \\
\text { Student is open to faith and } \\
\text { pursuing spiritual } \\
\text { commitment } \\
\text { Student is involved in some } \\
\text { extracurricular activities }\end{array}$ & $\begin{array}{l}\text { Variety in curriculum } \\
\text { IB/AP credit, dual } \\
\text { enrollment in community } \\
\text { college }\end{array}$ & $\begin{array}{l}\text { Look at activities and also } \\
\text { look at the transcripts and } \\
\text { seeing how much they've } \\
\text { been challenging themselves } \\
\text { Dual enrollment, AP } \\
\text { courses, online courses }\end{array}$ & $\begin{array}{l}\text { Look at test scores of } \\
\text { homeschooled students since } \\
\text { they usually have } 4.0 \text { GPAs } \\
\text { Helps to see how the student } \\
\text { is performing nationally } \\
\text { Committed, dedicated to } \\
\text { service, leadership, } \\
\text { diversity }\end{array}$ \\
\hline $\begin{array}{l}\text { Traditional vs. Proficiency } \\
\text { Grading }\end{array}$ & $\begin{array}{l}\text { "I feel like a lot of our } \\
\text { problems with traditional is } \\
\text { that the students are } \\
\text { ascribing the letter grade to } \\
\text { their worth and I feel like } \\
\text { we are trying to get away } \\
\text { from that, but if we } \\
\text { completely switch to } \\
\text { proficiency, won't we see the } \\
\text { same thing?" }\end{array}$ & $\begin{array}{l}\text { "In terms of evaluating } \\
\text { students in terms for } \\
\text { admissions, I think } \\
\text { traditional grades are } \\
\text { extremely helpful. There has } \\
\text { to be some type of } \\
\text { quantitative way to } \\
\text { distinguish students when } \\
\text { viewing them for undergrad } \\
\text { or grad schools; this helps } \\
\text { give more info about the } \\
\text { student." }\end{array}$ & $\begin{array}{l}\text { "Proficiency grading seems } \\
\text { a little more labor intensive } \\
\text { for the professor and requires } \\
\text { a student who actually wants } \\
\text { to absorb the knowledge } \\
\text { which are two rare } \\
\text { components...but overall } \\
\text { seems better for the student } \\
\text { and I like the philosophy } \\
\text { behind it." }\end{array}$ & $\begin{array}{l}\text { "I would prefer the move } \\
\text { toward proficiency grading } \\
\text { systems, but it would be hard } \\
\text { to determine the scale of it } \\
\text { and communicate it to } \\
\text { students and then to graduate } \\
\text { schools." }\end{array}$ \\
\hline $\begin{array}{l}\text { Future of Classroom } \\
\text { Assessment in College }\end{array}$ & \multicolumn{4}{|c|}{$\begin{array}{l}\text { Proficiency grading could be inserted for general education classes like public speaking or first-year seminar and traditional } \\
\text { grading could be applied in major classes. }\end{array}$} \\
\hline
\end{tabular}

\section{Future Research}

We hope to further this research study by locating at least 70 college students who graduated from proficiency-based secondary schools to inquire about their learning experiences and their views about grading systems. Although the numbers of students from proficiency-based grading backgrounds are more scarce, gathering data from this group would be insightful. It is clear from our interviews with the college admissions counselors that a myriad of grading systems is represented in the college applications process. Therefore, it would greatly benefit college applicants and their families if researchers investigated how more post-secondary institutions translate these diverse grading systems, especially now that many American universities have decided not to consider standardized assessments like SAT/ACT scores in the application process during the COVID-19 climate (Hoover 2020).

\section{CONCLUSION}

The initial idea for this study was born in a first-year seminar course where one of the members of our research team shared that her college experience felt different from the majority of her peers given that she graduated from a high school that had adopted a proficiency-based grading system. Our discussion led to questions such as: How do we measure learning in today's schools? How do grading systems impact student learning? And, how do college counselors account for this variance in evaluating students' academic performance in the admissions process? This study is beneficial to educational stakeholders because it sheds light on the impact of grading systems upon student learning and college admissions. Traditional grading has been understood universally, but it also focuses on the product of a letter grade, which promotes competition and stress. Proficiency-based grading offers students an alternative assessment method which 
focuses more on the process of learning; however, its non-traditional terms can be ambiguous and challenging.

University admissions counselors confirmed that there is minimal communication between secondary and post-secondary institutions about grading systems, and a standardized method to calculate the role of grades in the university admissions process does not exist. Herein lies a gap that is now acknowledged and should be revised. Moreover, the college counselors interviewed for this study shared that they referred to standardized testing to provide a norm-referenced comparison for college applicants' academic performance. Yet, in America, many post-secondary institutions have removed standardized testing in college admissions during the COVID-19 climate. Without completion of a standardized test like the SAT or ACT, new challenges arise in how to accurately assess college readiness and evaluate intellectual preparedness using a common tool. In light of the pandemic, schools across the U.S. are now approaching grading from many different angles, such as a credit/no credit system, switching to a proficiency-based system, or even eliminating grades altogether (Davidson \& Katopodis, 2020). This emergency switch to distance learning has revolutionized the purpose and meaning of grades and qualifications for college admission, leaving an impact that will likely transform the educational system.

\section{ACKNOWLEDGEMENT}

We would like to acknowledge the support of the Office of the Provost of Research and the Office of Admissions at Pepperdine University.

\section{REFERENCES}

Childs, P., \& Stromquist, N.P. (2015). Academic and diversity consequences of affirmative action in Brazil. Compare: A Journal of Comparative and International Education, 45(5), 792-813. doi: $10.1080 / 03057925.2014 .907030$

Conley, D. (2015). A new era for educational assessment. Education Policy Analysis Archives, 23(8), 141.

Cox, K.B. (2011). Putting classroom grading on the table: A reform in progress. American Secondary Education, 40(1), 67-87.

Davidson, C.N., \& Katopodis, C. (2020). In a pandemic, everyone gets an asterisk. Inside Higher Ed. Retrieved from https://www.insidehighered.com/views/2020/03/23/during-covid-19-crisis-highered-should-rethink-how-assess-test-and-grade-students

Goodwin, B. (2011, November). Grade inflation: Killing with kindness. Educational Leadership, pp. 8081.

Great Schools Partnership. (2015). Assessment. Retrieved from https://www.edglossary.org/assessment/

Guskey, T. (2001). Helping standards make the grade. Educational Leadership, 59(1), 20-27.

Hiss, W.C., \& Franks, V.W. (2015, Summer). Brave new world: How test optional policies could (and should) change college admission. The Journal of College Admission, pp. 32-34.

Hochbein, C., \& Pollio, M. (2016). Making grades more meaningful. Phi Delta Kappan, 98(3), 49-54. doi: http://dx.doi.org.lib.pepperdine.edu/10.1177/0031721716677262

Hoover, E. (2020, June 7). Testing shakeup: Caltech won't consider ACT/SAT scores for next 2 years. Retrieved from https://www.chronicle.com/article/Testing-Shakeup-

Caltech/248938?utm_source=Iterable

\&utm_medium=email \&utm_campaign=campaign_1270754\&cid=gb\&source=ams\&sourceId=52 22041

Iamarino, D.L. (2014). The benefits of standards-based grading: A critical evaluation of modern grading practices. Current Issues in Education, 17(2), 1-10. Retrieved from

http://cie.asu.edu/ojs/index.php/cieatasu/article/view/1234

Marzano, R. (2000). Transforming classroom grading. Alexandria, VA: ASCD. 
McKenna, L. (2018). Will letter grades survive? Retrieved from https://www.edutopia.org/article/willletter-grades-survive

Møen, J., \& Tjelta, M. (2019, June). Grading standards, student ability, and errors in college admission. Scandinavian Journal of Educational Research, 54(3), 221-237. doi: $10.1080 / 00313831003764503$

Nahai, R.N. (2013). Britain: Is meritocracy fair? A qualitative case study of admissions at the University of Oxford. Oxford Review of Education, 39(5), 681-701. doi: 10.1080/03054985.2013.843447

Nolan, J. (2016). Growing mastery in NYC. Phi Delta Kappan, 98(3), 41-48. doi: $10.1177 / 0031721716677261$

Peters, R., Kruse, J., Buckmiller, T., \& Townsley, M. (2017). “It's just not fair!” Making sense of secondary students' resistance to standardized grading. American Secondary Education, 45(3), 9-28.

Pippin, T. (2014). Roundtable on pedagogy: Response: Renounce grading? Journal of the American Academy of Religion, 82(2), 348-355. https://doi-org.lib.pepperdine.edu/10.1093/jaarel/lfu002

Rawlins, J., \& Ishikura. Y. (2017, Fall). Admission reform in Japan: Why Osaka University is transforming its practices. The Journal of College Admission, pp. 47-49.

Robson, C. (2007). How to do a research project. Maiden, MA: Blackwell Publishing.

Sabee, C.M., \& Wilson, S.R. (2005). Students' primary goals, attributions, and facework during conversations about disappointing grades. Communication Education, 54(3), 185-204. doi: $10.1080 / 03634520500356154$

Scriffiny, P.L. (2008, October). Seven reasons for standards-based grading. Educational Leadership, $66(2), 70-74$.

Shea, M. (2017). Three reasons non-traditional grading won't affect college acceptance. Retrieved from https://knowledgeworks.org/resources/cbe-grading-college-acceptance/

Soares, J.A. (2012). The future of college admissions: Discussion. Educational Psychologist, 74(1), 6670. doi: $10.1080 / 00461520.2011 .638902$

Sorey, K., \& Duggan, M.H. (2008). Homeschoolers entering community colleges: Perceptions of admissions officers. Journal of College Admission, 200, 22-28.

Sternberg, R.J., Bonney, C.R., Gabora, L., \& Merrifield, M. (2012). WICS: A model for college and university admissions. Educational Psychologist, 47, 30-41. doi: $10.1080 / 00461520.2011 .638882$

Tam, M., \& Sukhatme. U. (2004, Spring). Make better college admission decisions: Considering high school quality and other factors. The Journal of College Admission, pp. 12-16.

Verrell, P.A., \& McCabe, N.R. (2015). In their own words: Using self-assessments of college readiness to develop strategies for self-regulated learning. College Teaching, 63(4), 162-170. doi:

$10.1080 / 87567555.2015 .1053046$ 


\section{APPENDIX A: SURVEY FOR STUDENT PARTICIPANTS}

\section{Background}

Traditional Grading: The most well-known and common form of grading style throughout the United States. Students are graded through tests, quizzes, and homework. This system utilizes letter grades of A, $\mathrm{B}, \mathrm{C}, \mathrm{D}, \mathrm{F}$.

Proficiency Grading: An up-and-coming grading style that is based on students' proficiency of set standards. Assessments are either formative or summative. Formative assessments (can be compared to homework) monitor student learning and give feedback. Summative assessments (can be compared to tests) evaluate student learning. Proficiency grading is focused on the progress of learning, rather than just the letter grade. Students have the ability to retake summative assessments in order to prove their proficiency. This system utilizes grades of mastery (MAS), advanced (ADV), meets (MTS), approaching (APP), and beginning (BEG).

1. Gender

2. College or University you attended in the 2017-2018 academic year.

3. Which high school did you graduate from?

4. What was your high school GPA?

5. Did your former high school use the traditional or proficiency grading style?

6. In high school, I was generally more concerned about my grades than learning the content in my classes. (Likert Scale: Strongly Disagree: 1 to Strongly Agree: 5)

7. List all the courses you took in your first year in college/university.

8. My college courses have been significantly more difficult than my high school. (Likert Scale: Strongly Disagree: 1 to Strongly Agree: 5)

9. My high school's grading style readily prepared me for success in college. (Likert Scale: Strongly Disagree: 1 to Strongly Agree: 5)

10. I believe the grading style my school did NOT use (traditional and proficiency) would have been more beneficial. (Likert Scale: Strongly Disagree: 1 to Strongly Agree: 5)

11. How did you feel about the grading system your high school used? How did it help or hinder learning while in high school?

12. If you were a high school administrator, which grading system (traditional or proficiency) would you be more inclined to adopt and why?

13. How specifically did your high school's grading system fail or help to prepare you for your college academic experience?

14. How did your high school's grading system affect your view towards learning and education in general?

15. Please share any final thoughts that you may have regarding your high school grades and your college experience. 


\section{APPENDIX B: INTERVIEW GUIDE FOR COLLEGE ADMISSIONS COUNSELORS}

Main Question: How do traditional and proficiency-based grading schemes impact college admissions, preparedness, and learning?

\section{Grades: Admissions \& College Preparedness}

-How are grades considered when reviewing college applications?

- Do you feel grades accurately represent a student's ability to succeed in college?

- How heavily are grades weighted in the admissions process?

-What types of grading systems do you see when reviewing students' applications?

- What is the most common form of grading?

- What percentage of applicants come from traditional grading? Proficiency-based? Other?

- How do you see families manipulating grading systems for college applications?

-How do high school grades impact students' college experiences?

- Do high school grades have a positive or negative impact on learning in college?

- Have you seen or heard of any evidence that leads you to believe that students who come from traditional or proficiency-based grading systems have any advantages or are more welladjusted to the academic environment at the university?

\section{Learning: Traditional vs. Proficiency Grading}

-Is it more beneficial overall to have traditional or proficiency grading in college?

- What do you see as the major pros and cons of traditional grading?

- What do you see as the major pros and cons of proficiency-based grading?

-Would you adopt proficiency or traditional grading as a college professor? Explain.

- How do you feel this grading system would benefit you as a student?

\section{Learning: Grading Systems in College}

-Do you think it would be possible for universities to adopt both traditional and proficiencybased grading systems? For example, traditional grades could be allotted for certain academic courses (e.g., English, history), while proficiency-based grading could be implemented for others (e.g., public speaking, first-year seminar). 